\title{
The Concept of Love in Dostoyevsky's White Nights
}

\author{
Mohammad Yousefvand (Corresponding author) \\ Department of English language and literature, Razi University, Iran \\ E-mail: mmyousefvand@gmail.com \\ Hamid Tatari \\ Department of English language and literature, University of Lorestan, Iran
}

Received: $15-12-2014$

Published: 01-07- 2015
Accepted: 24-02- 2015

doi:10.7575/aiac.ijalel.v.4n.4p.231 URL: http://dx.doi.org/10.7575/aiac.ijalel.v.4n.4p.231
Advance Access Published: February 2015

\begin{abstract}
Love is a phenomenon we are involved with in our life. The concept of love has been immensely discussed and challenged by philosophers and psychologists all throughout the history because of its salient and effective role in our individual and social lives. Self-love and altruistic love, two main types of love, have been repeatedly reflected in psychologists' works; self-love refers to a kind of love which is based on psychological egoism; on the other hand, altruistic love is conceived of as a sort of love which is principally based on selflessness, caring, respect, and sacrifice. "White Nights" is a short story by Fyodor Dostoyevsky which seemingly has an altruistic view toward love; it sounds that Dostoyevsky has made a purposeful attempt to praise such altruistic love in the story. Thus, it has been tried to delve into the concept of love manifested in White Nights. This paper is divided into two parts; in the first part, a theoretical framework entailing definitions of love and its types is depicted; in the second part, an account of how love is emerged in the story will be explained. At last, this paper substantiates that altruistic love is represented and admired in this story and is preferred to the other types of love.
\end{abstract}

Keywords: The Concept of Love, Family Resemblance, Types of Love, Triangular Theory of Love, Self-love, Altruistic Love

\section{Introduction}

Analytical philosophers, especially philosophers of language, believe that each word used in our language must be distinctively defined. Determining the meaning of a word is prior to discussing about it. The concepts are divided into concrete concepts and abstract ones. Concrete concepts are those which are touchable; that is, they can be touched and defined by showing and referring; this kind of definition is called as the "referential definition". 'But for instance, the concept of love - that is what we are primarily concerned with in this paper- is an abstract concept; that is to say, it is a word unattached to anything real, sensible or tangible; this definition called as the "conceptual definition". Defining abstract concepts is more complex than the concrete ones, since we are not dealing with something touchable and it cannot be shown, so defining them requires more complicated methods as well. One of the best methods for defining such concepts is using Wittgenstein ${ }^{21}$ s family resemblance theory. In order to explain this theory, Wittgenstein employs the notion of Language Games. In simple terms, this theory helps us to define an abstract concept based on its common features that are seen in the real life. ${ }^{3}$ In this paper, this method will be used to define love.

In throughout history, the concept of love is debated by many thinkers. These thinkers have been mainly the philosophers. From the Greek time, the great philosophers such as Socrates, Plato and Aristotle have argued about the definition, meaning and nature of love. The philosophical discussion concerning love begins with questions regarding its nature. In his famous book Symposium, Plato (1998) discusses about love in a dialogic form, concluding that the best form of love is the platonic love (love without sexual attraction) and it is more valued and qualified than the others. These arguments continued since the beginning of twentieth century. By the development of empirical sciences such as biology, psychology and sociology at the beginning of twentieth century, the arguments about love have opened its way into these fields. A psychologist studies psychological causes and effects of love and a Biologist concerns with the biological and physiological aspects of love. Empirical approach's attempts to work on this phenomenon have made the views much broader and deeper.

When everyone thinks about love, such important questions can be raised in his/her mind:

1. What is the definition of love? What is the meaning of love?

2. What is/are the origin/origins of love?

3. What are the forms/kinds/branches of love?

1. For further reading, see: Frege, Gottlob. Translations from the Philosophical Writings of Gottlob Frege. ed. Peter Geach and Max Black (Oxford: Blackwell, 1952), pp. 56-78.

2. Ludwig Wittgenstein (1889-1951) - An Austrian philosopher who is known for having inspired two of the century's principal philosophical movements, logical positivism and ordinary language philosophy.

3. For further reading, see: Wittgenstein, Ludwig. Philosophical Investigations, tr. G.E.M. Anscombe. Oxford: Blackwell, 1963 
4. Which form is superior to the others? Which one is more sublime?

5. What is the relationship between love and the other existential phenomena such as faith, loneliness, hope, silence and pain?

Accordingly, reading the story of "White Nights" readers' minds:

1. Which form of love has been notable for Dostoyevsky?

2. With which existential problems the characters are involved and how the characters confront with them? What is the role of love in this situation?

3. Are we are dealing with a giving love or receiving one in this story?

4. Does this love make the characters active or passive?

5. Is this love welcomed to the characters or not?

6. Does this love cure characters psychologically or not?

In the first part, this article will try to give logical answers to these questions in the philosophical and psychological views, and then in the second part, these answers will be applied to and extracted from the White Nights. First, this paper deals with a theoretical framework, and then a practical criticism will be represented based on it.

\section{Part I: The Concept of Love}

\subsection{Definition of Love}

From ancient to present time, various definitions have been offered for love. Philosophical investigation of love includes the tasks of distinguishing between various kinds of personal love, asking if and how love is or can be justified, and inquiring about the value of love is. Although some thinkers believed that abstract concepts cannot be defined in general and love in particular, some philosophers believe that love is definable and its conceptual clarification is of crucial importance. Everyone has a conceptual image of love; generally speaking, many people understand love as an intense feeling of affection and care toward another person; some people may construe it as a deep or abiding liking for somebody/something. Although these definitions are not wrong, they are not comprehensive and precise; thus we must present a definition encompassing all possible forms and aspects of love. First, it is better to take a look at one of the most famous psychological theories about love, and then an exact definition will be provided.

\subsubsection{Robert Sternberg's viewpoint toward love}

One of the most famous theories that clarify love is Robert Sternberg's triangular theory of love. According to Sternberg (2007, p 332), "the three components of love are an intimacy component, a passion component, and a decision/commitment component".

1. Intimacy - which encompasses feelings of attachment, closeness, bond, and connectedness

2. Passion - which encompasses drives connected to both limerence and sexual attraction

3. Commitment - which encompasses the decision to remain with another, and in the long term, plans made with that other. (Sternberg, 1986, pp. 119-135)

This theory can be shown in a triangular figure like below:

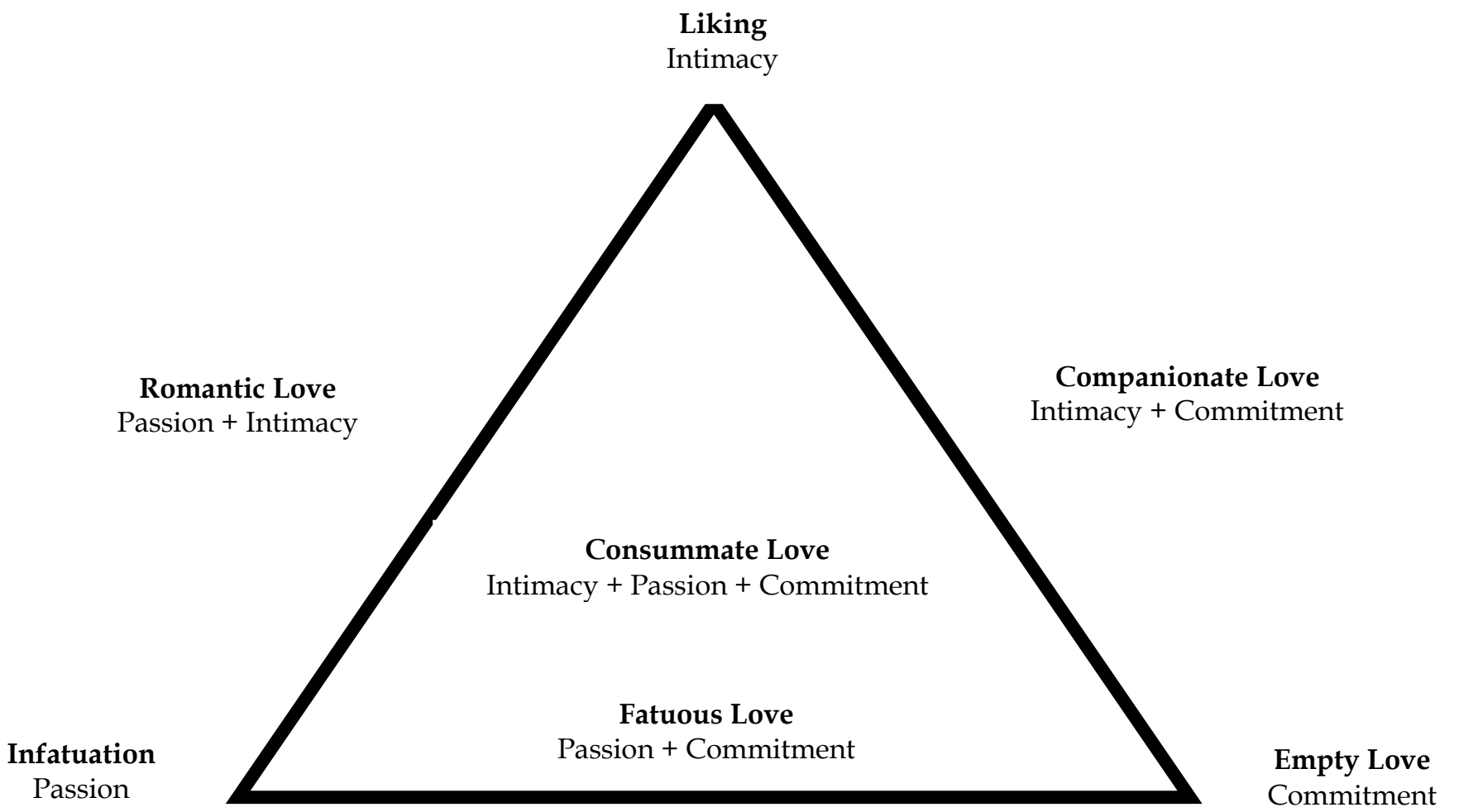

Figure 1. Robert Sternberg's Triangular Theory of Love 
Intimacy is a form in which two people share confidences and various details of their personal lives, and is usually emerged in friendships and romantic love affairs. The most common form of love is sexual attraction and passion. Passionate love well crystallized and portrayed in infatuation as well as romantic love. The last one is commitment; the expectation that the relationship is permanent. All forms of love are viewed as varying combinations of these three components. Non-love does not include any of these components. Liking only includes intimacy. Infatuated love only includes passion. Empty love only includes commitment. However, romantic love includes both intimacy and passion. Companionate love includes intimacy and commitment. Fatuous love includes passion and commitment. Lastly, consummate love entails all three components. (ibid, pp. 119-135)

2.1.2 Love definition based on Wittgenstein's Family Resemblance ${ }^{4}$

Table 1. Various Theories of Love accompanying their Salient Features

\begin{tabular}{|c|c|}
\hline Definition, Theory or Type & Features \\
\hline $\begin{array}{l}\text { Oxford Advanced Learner's Dictionary, 8th } \\
\text { edition }\end{array}$ & $\begin{array}{l}\text { a strong feeling of deep affection for sb/sth, sexual } \\
\text { attraction, passion, adore, and desire }\end{array}$ \\
\hline Robert Sternberg's theory & intimacy, commitment, and passion \\
\hline Erich Fromm's theory & affection, commitment, altruism, and care \\
\hline Agapetic love & $\begin{array}{l}\text { affection, pure, ideal love not physical one, care, and } \\
\text { sacrifice }\end{array}$ \\
\hline Erotic love & affection, passion, physical and sensual desire \\
\hline Self-love & affection, intimacy, sexual attraction, and passion \\
\hline Altruism & affection, intimacy, care, commitment, and sacrifice \\
\hline
\end{tabular}

A new definition must be represented because the definitions which are stated in long history are not all-inclusive; it means they don't include all possible forms of love. As mentioned, according to family resemblance, for defining of a concept, the common features of all forms of that concept must be determined, and then these features construct a pattern which is our definition. Suppose we have a concept called A. The possible forms of A are A1, A2, and A3. The features of $\mathrm{A} 1$ are $\mathrm{b}, \mathrm{c}, \mathrm{x}, \mathrm{y}, \mathrm{z}$ and the features of $\mathrm{A} 2$ are c,d,k,y,r,z and the features of $\mathrm{A} 3$ are c,d,t,h,z,s, so the common features of A1, A2, and A3 are $\mathrm{c}$ and $\mathrm{z}$. these two features construct a pattern, so A can be defined as something that has two features: $\mathrm{c}$ and $\mathrm{z}$. We also apply this method to concept of love. Thus, in order to establish a comprehensive definition, the common features of all forms of love must be determined. To do so, all definitions, theories and types of love (these types will be explained in next section) helping us in this work must be taken into account. It is worthy to point out that types that are similar to what we have listed here have not been mentioned. All available types and definitions are summarized in Table 1 so as to extract the commonalities more precisely.

Therefore, the conclusion can be drawn that live is "a strong feeling of affection toward sb/sth that arouses emotional attraction [in some types of love is appeared as sexual attraction and in the others as care], and causes such feelings as intimacy, passion, and desire".

\subsection{Types of Love}

There are three main classifications of love that each one divides love into some types: general classification, Greek classification, and psychological-existential classification. Further, in the general classification, love is divided into two types: impersonal and interpersonal. Ancient Greek classified love into four types: eros, agape, philia, and storge. In the psychological-existential classification, love is classified as self-love and altruism. Each of the above-mentioned categories and their sub-classification will be elaborated upon in the following.

\subsubsection{General category of Love}

\subsubsection{Impersonal Love}

Impersonal love refers to "love an object, principle, or goal" to which they are deeply committed and greatly value. For example, compassionate outreach and volunteer workers' "love" of their cause may sometimes be born not of interpersonal love but impersonal love, altruism, and strong spiritual or political convictions (Fromm, 1956). In impersonal love, beloved is non-human. In this love, if sexual passion is involved, then this feeling is called paraphilia. (American Psychiatric Association, 2000, pp. 566-76)

4. The theory applied here for defining love is the Wittgenstein's family resemblance theory. It also can be used for defining any other abstract concepts. Wittgenstein proposed this theory for the first time in his Philosophical Investigation. 


\subsubsection{Interpersonal Love}

Interpersonal love refers to "love between human beings". It is a more potent sentiment than a simple liking for another. Unrequited love refers to those feelings of love that are not reciprocated. Interpersonal love is most closely associated with interpersonal relationships (Fromm, 1956). In this type of love, both lover and beloved are human beings.

\subsubsection{Greek Types of Love}

\subsubsection{Eros}

Eros is a passionate love; intimate love or romantic love, with sensual/sexual desire and longing. It has also been translated as "love of the body". Nygren (1953) describes eros as the "love of desire" or acquisitive love and therefore as egocentric, Soble (1990) similarly describes eros as "selfish". In Freudian psychology, "Eros is strictly the sexual component of our life" (Freud, 1925, pp. 163-74), not to be confused with libido which Freud referred to as our life force, the will to live. Although eros is initially felt for a person, with contemplation it becomes an appreciation of the beauty within that person, or even becomes appreciation of beauty itself. "Erotic love" has its roots in this type.

\subsubsection{Agape}

Agape generally refers to a pure and ideal type of love, rather than the physical attraction suggested by eros. It has also been translated as "love of the soul". It refers to the paternal love of God for man and of man for God but is extended to include a brotherly love for all humanity. In the New Testament, it refers to the covenant love of God for humans, as well as the human reciprocal love for God. It is also known as "agapetic love".

\subsubsection{Philia}

Philia refers to a dispassionate virtuous love; it is a concept addressed and developed by Aristotle ${ }^{5}$. It originally meant a kind of affectionate regard or friendly feeling toward not just one's friends but also possibly toward family members, business partners, and one's country at large (Liddell et al., 1940; Cooper, 1977). In fact, it includes loyalty to friends, family, and community, and requires virtue, equality, and familiarity. Philia is translated as "brotherly love".

\subsubsection{Storge}

Storge is a natural affection, like that felt by parents for offspring. It is also known as "motherly love", it means the mother-child relationship. "Motherly love is unconditional affirmation of the child's life and his needs. In contrast to brotherly love and erotic love which are love between equals, the relationship of mother and child is by its very nature one of inequality, where one needs all the help, and the other gives it". (Fromm, 1956)

\subsection{Psychological-Existential Classification of Love}

\subsubsection{Self-Love}

For clarifying these two types of love, it's better to explain them in a logical form. Suppose your beloved is "x", so in self-love: You love "x", but you want "x", you want to achieve him/her. In this love, in fact, you love "x", but you think and focus on yourself not " $\mathrm{x}$ ". It should not be intermingle with narcissism; in narcissism, a person loves oneself, but in self-love, a person loves " $x$ " for oneself. The central concept in this love is psychological egoism. "Loving oneself is different from being arrogant, conceited or egocentric. Loving own self means caring about oneself, taking responsibility for oneself, respecting oneself, and knowing oneself." (Fromm, 1956)

\subsubsection{Altruism}

In altruism or selflessness, you love "x", but you concern to his/her happiness and success. Altruism consists of sacrificing something for someone other than the self (e.g. sacrificing time, energy or possessions) with no expectation of any compensation or benefits.

\section{PART II: Love in White Nights}

\subsection{Synopsis}

"White Nights ${ }^{6}$ is a short story by Fyodor Dostoyevsky, originally published in 1848, early in the writer's career. Like many of Dostoyevsky's stories, "White Nights" is told in first person by a nameless narrator; the narrator is living in Saint Petersburg and suffers from loneliness. He gets to know and falls in love with a young woman named Nastenka, but the love remains unrequited as the woman misses her lover with whom she is finally reunited.

\subsection{Plot summary ${ }^{7}$}

The story is divided into six sections; first Night, second night, Nastenka's Story, third night, fourth night, morning. In the first night, the narrator describes his experience walking in the streets of St. Petersburg. He lives alone in a small apartment in Saint Petersburg with only his older, non-social maid Matryona to keep him company. He tells the story of his relationship with a young girl called Nastenka. He first sees her standing against a railing while crying. The main

5. For further reading, see: Aristotle. Nicomachean Ethics, dual text, with translation by H. Rackham. Harvard University Press, 1934

6. This work takes its title from the long twilight periods that, during the warm months of the year, last nearly until midnight in northern lands, including some parts of Russia.

7. The plot of the story is taken from this website:

http://en.wikipedia.org/wiki/White_Nights_short_story 
character feels timid and begins shaking while she holds his arm. The girl is as lonely as the narrator. In the second night, Nastenka introduces herself to him and the two become friends by relating to each other. The main character defines himself as a dreamer. The third part is where Nastenka relates her life story to the narrator. She lived with her strict grandmother who gave her a largely sheltered upbringing. Her grandmother's pension being too small, they rent out their house to gain income. When their early lodger died, he was replaced by a younger man closer to Nastenka's age much to her grandmother's distaste. The young man begins a silent courtship with Nastenka. Upon the night that the young lodger is about to leave Petersburg for Moscow, Nastenka escapes her grandmother and urges him to marry her. He refuses immediate marriage, stating that he does not have money to support them but he assures her that he would return for her exactly a year later. Nastenka finishes her story at the end of this, noting that a year has gone and he hasn't sent her a single letter. In the third night, the narrator gradually realizes that despite his assurance that their friendship would remain platonic, he has inevitably fallen in love with her, but he hides away his feelings for her. In the fourth night, Nastenka states that maybe their relationship might become romantic some day, but she obviously wants his friendship in her life. The narrator becomes hopeful at this prospect when during their walk, they pass by a young man who stops and calls after them. He turns out to be Nastenka's lover into whose arms she jumps and leaves the narrator alone. In the morning, the final section is a brief afterword that relates a letter which Nastenka sends him apologizing for hurting him and insisting that she would always be thankful for his companionship. She also mentions that she would be married within a week and hoped that he would come. The narrator breaks into tears upon reading the letter. The narrator, however, refuses to despair at the end of the story.

\section{Love in the story}

In Fyodor Dostoevsky's short story "White Nights", his unnamed protagonist is a sensitive, poetic resident of the much modernized St. Petersburg of the mid-nineteenth century. He defines himself as a "dreamer". He is drowned in his imagination. One night he was passing in the way to his house, when an unexpected adventure happened to him, he saw his beloved, Nastenka, for the first time; it was the first night of their acquaintance. In the first night, Nastenka wants the boy to give her a promise: "I am ready for friendship; here's my hand... but you mustn't fall in love with me, I beg you!" and the boy accepts. In the second night, they get closer to each other by telling their stories but the relationship remains as friendship yet, not more; the boy begins to tell his story by speaking about his perpetual dreams, and then Nastenka recounts what has happened to her. She tells him that she lives with her grandmother, and reveals the fact the she has a beloved who has promised to marry her, but last year he has told her that he has to go to Moscow and he had gone away, and she has received no news from him up to now; nevertheless, she has waited for him in this long period. The narrator gradually realizes that he has a deep emotional feeling toward Nastenka; he feels that he has fallen in love with her but it seems an unrequited love in his view. In the fourth night, the narrator reveals his feeling and confesses his love, but Nastenka wants him to be her friend not more. In this time, a young man appears to them and approaches Nastenka. The narrator turns out that he is Nastenka's beloved. Both Nastenka and her beloved leave the narrator alone and disappear in the darkness. In the morning, Natenka sends the narrator a letter apologizing him and tells him that she wants to marry. But at the end, the narrator doesn't become hopeless and sad, so he drafts a letter to Nastenka and thanks her so much. In the following, a more precise analysis of love in the story based on Sternberg's theory of love and its types is presented.

\subsection{Analysis of love based on Sternberg's Triangular theory of love}

The theory of love in Sternberg's view explained in the first part, now we want to apply this theory to the story. In this theory love has three phases; intimacy, passion, and commitment. These three phases form seven different kinds of love experiences. Combinations of intimacy, passion, commitment shape seven different kinds of love that can be listed in a table like below:

Table 2. Combinations of Intimacy, Passion, and Commitment

\begin{tabular}{lccc}
\hline & Intimacy & Passion & Commitment \\
\hline $\begin{array}{l}\text { Nonlove } \\
\text { Liking/friendship }\end{array}$ & $\mathrm{x}$ & & \\
\hline Infatuated love & & $\mathrm{x}$ & $\mathrm{X}$ \\
Empty love & $\mathrm{x}$ & $\mathrm{x}$ & $\mathrm{x}$ \\
Romantic love & $\mathrm{x}$ & & $\mathrm{x}$ \\
Companionate love & & $\mathrm{x}$ & $\mathrm{x}$ \\
Fatuous love & $\mathrm{x}$ & $\mathrm{x}$ & \\
\hline
\end{tabular}

In the first night, the two characters become familiar with each other and in the second night, they recount their story for each other. In these two nights, intimacy is formed between them; it means they are in the first phase of love "liking/friendship". In the third night, the narrator is attracted to Nastanka more and more, and he enters into the second phase of love based on passion, but Nastenka remains in the first phase. In fourth night, the narrator gets in a deep emotional feeling and reveals it. In this night, he is in the second part yet, and Nastenka remains in the first phase yet. In the morning, they become separate from each other and commitment that is the third phase of love is not formed 
between them, so the narrator that is dealing with intimacy and passion, experiences romantic love, he is bonded both intimately and passionately without sustaining commitment, and Nastenka remains in the intimacy and only experiences liking/friendship without emotional attachment and commitment, she feels closeness, bondedness, and warmth toward the narrator, without feelings of intense passion or commitment.

\subsection{Analysis of love based on types of love}

\subsubsection{Analysis of love based on the first classification of types of love}

Impersonal and Interpersonal: It is obvious that two characters are dealing with interpersonal love not impersonal one, because two characters love each other and both of them are human beings. It may be said that the narrator loves his dreams at the beginning of the story and the dream is non-human element, but although the dream is non-human element but he doesn't love his dreams, he is involved with them and is tired of them and wants to escape from them. These dreams bother him. He finds Nastenka and falls in love with her because Nastenka makes him get rid of these disturbing dreams.

\subsubsection{Analysis of love based on the second classification of types of love}

Nastenka's love toward the narrator is limited only to friendship, so it can be said that her love is philia; it means her love is motivated by practical reasons, one or both of the parties benefit from the relationship. At first, the narrator also is involved with this type of love but as his love grows and gets deeper, it changes from philia to agape; it means the narrator's love is developed from friendship and togetherness to spiritual attraction.

\subsubsection{Analysis of love based on the third classification of types of love}

At the end of the story, the narrator only wants to take care of Nastenka; it means he deals with an altruistic love not a self-love. He wants Nastenka for her being; he does not think to possess her. Self-love is based on egoism but altruistic love is based on selflessness, so the narrator is devoted to Nastenka altruistically not egoistically. Nastenka's love is altruistic too, but altruism that is based on selflessness, care, responsibility, and sacrifice is so stronger in the narrator than Nastenka. The last statements of the story prove this idea very well. In this excerpt, when narrator is sad for his separation from his beloved and becomes aware of his beloved's marriage, instead of getting angry and becoming sad and hopeless, he notes a letter that shows his altruistic attitude toward his beloved, he says: "But to imagine that I should bear you a grudge, Nastenka! That I should cast a dark cloud over your serene, untroubled happiness; that by my bitter reproaches I should cause distress to your heart, should poison it with secret remorse and should force it to throb with anguish at the moment of bliss; that I should crush a single one of those tender blossoms which you have twined in your dark tresses when you go with him to the altar... Oh never, never! May your sky be clear, may your sweet smile be bright and untroubled, and may you be blessed for that moment of blissful happiness which you gave to another, lonely and grateful heart! My God, a whole moment of happiness! Is that too little for the whole of a man's life? (Dostoevsky, 1918, p. 49)"

\section{Conclusion}

In this story, the authors have a specific attitude toward love that we prefer to call it an "existential love". Dostoyevsky's White Nights represents a form of love that is based on sacrifice not selfishness, altruism not egoism, and being not having ${ }^{8}$. The narrator's love is a progressive love, but Nastenka's love is a fixed one. The characters' love toward each other can be shown like this:

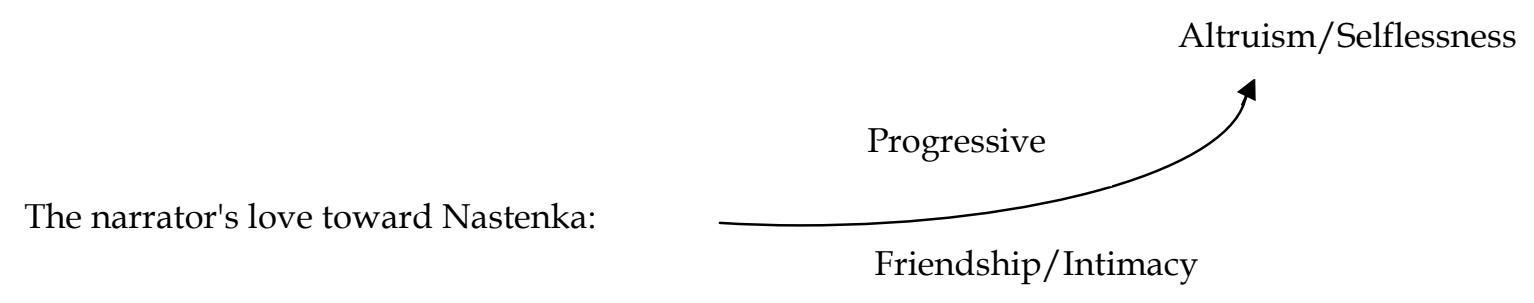

Nastenka's love toward the narrator:

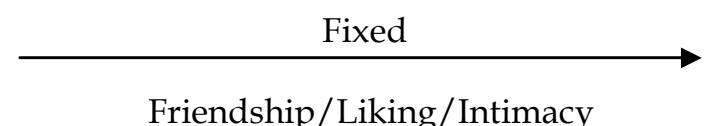

Friendship/Liking/Intimacy

The author admires the narrator's love because it is based on intimacy, pure love, care, giving, altruism, selflessness, and sacrifice; in this love mental health and moral virtues and spiritual progress are achieved for the lover.

8. Fromm has a similar argument in his famous book having or being. He believes that in order to have a moral society, individuals must behave focusing on being not having. He says that being leads the person to selflessness, but having leads the person to selfishness. 


\section{References}

American Psychiatric Association (June 2000). Diagnostic and Statistical Manual of Mental Disorders-IV (Text Revision). Arlington, VA, USA: American Psychiatric Publishing, Inc.

Cooper, J. M. (1977). Aristotle on the Forms of Friendship. Review of Metaphysics, 30: pp. 619-48.

Dostoevsky, Fyodor. (1918). White Nights and Other Stories, tr. Constance Garnett. New York: THE Macmillan Company.

Freud, S. (1925). The Resistances to Psycho-Analysis in The Collected Papers of Sigmund Freud, tr. James Strachey. Vol. 5. London: The Hogart Press and the Institute of Psychoanalysis.

Fromm, E. (1956). The Art of Loving. New York: Harper \& Row.

Nygren, A. (1953). Agape and Eros. Philadelphia, PA: Westminster Press.

Plato. (1998). The Symposium, trans. by Robin Waterfield. Oxford: Oxford University Press.

Soble, A. (1990). The Structure of Love. Yale University Press.

Sternberg, R. J. (1986). A triangular theory of love. Psychological Review, 93.

. ( 2007). Triangulating Love in Oord, T. J. The Altruism Reader: Selections from Writings on Love, Religion, and Science. West Conshohocken, PA: Templeton Foundation.

Wittgenstein, L. (1963). Philosophical Investigations, trans. By G.E.M. Anscombe. Oxford: Blackwell.

\section{Web Sites}

1. http://en.wikipedia.org/wiki/White_Nights_short_story

2. http://www.britannica.com/EBchecked/topic/662884/agape

3. http://plato.stanford.edu/entries/love/

4. http://www.iep.utm.edu/love/ 